\title{
SUKSESI MIKROBIA TERHADAP PENURUNAN ETANOL, ASAM LAKTAT DAN ASAM ASETAT SELAMA FERMENTASI BIJI KAKAO
}

\author{
Mulono Apriyanto \\ Program Studi Teknologi Pangan, Fakultas Pertanian, Universitas Islam Indragiri \\ Jln. Propinsi Parit 1 Tembilahan Hulu, Indragiri Hilir \\ mulonoapriyanto71@gmail.com
}

\begin{abstract}
Abstrak
Tujuan penelitian adalah: 1) mengetahui komposisi pulp biji kakao asalan sebagai subtrat untuk fermentasi; 2) mengevaluasi pengaruh variasi teknik fermentasi biji kakao asalan terhadap populasi mikrobia. Tahapan penelitian yang dilakukan adalah sebagai berikut (1) pengujian komposisi dan kadar air pulp biji kakao asalan sebagai subtrat fermentasi. (2) Fermentasi biji kakao asalan dengan 3 variasi teknik fermentasi yaitu pertama perlakuan tanpa penambahan inokulum (kontrol), kedua menggunakan inokulum $S$. cerevisiae (FNCC 3056), L. lactis (FNC 0086) dan $A$. aceti (FNCC 0016), masing-masing sekitar 108 cfu/g diberikan serentak diawal fermentasi (IA). (3) pemberian inokulum secara bertahap yeast di awal fermentasi, bakteri asam laktat pada jam ke 24 dan bakteri asam asetat pada jam ke 48 dengan populasi mikrobia sama dengan perlakuan kedua (IB). Fermentasi dilaksanakan selama 120 jam. Suhu diatur selama fermentasi, berturut-turut $35{ }^{\circ} \mathrm{C}(24 \mathrm{jam}$ pertama), $45{ }^{\circ} \mathrm{C}$ (24 jam kedua), $55{ }^{\circ} \mathrm{C}$ (24 jam ketiga) dan $35{ }^{\circ} \mathrm{C}$ (48 jam terakhir). Hasil penelitian menunjukan bahwa selama fermentasi biji kakao asalan menunjukan seluruh perlakuan terjadi peningkatan kosentarsi etanol sejalan dengan meningkatnya populasi $S$. cerevisiae diawal fermentasi. Selanjutnya L. lactis meningkat diikuti asam laktat, diakhir fermentasi $A$. aceti meningkat diikuti asam asetat. Dari hasil penelitian ini dapat disimpulkan bahwa rehidrasi pulp biji kakao asalan dapat memperbaiki komposisi pulp sebagai subtrat fermentasi. Populasi mikrobia menunjukan telah terjadi suksesi mikrobia ditunjukan pada perlakuan penambahan inokulum secara bertahap.
\end{abstract}

Kata Kunci : Biji kakao asalan, fermentasi, inokulum, etanol, asam laktat dan asam asetat

\section{PENDAHULUAN}

Produksi biji kakao kering dari perkebunan rakyat pada umumnya tidak menggunakan proses fermentasi baik secara alami maupun dengan penambahan inokulum. Pada umumnya petani kakao hanya merendam biji kakao segar dalam air dalam upaya untuk membantu menghilangkan pulp dan menjemur. Biji kakao kering yang tidak diketahui kadar airnya, dijual tanpa memperhatikan kualitas baik dari aspek kadar air maupun kondisi biji kering disebut sebagai biji kakao asalan.

Fermentasi adalah salah satu faktor penting dalam pengolahan biji kakao khususnya dalam pembentukan senyawa prekusor flavor. Fermentasi biji kakao 
segar terdiri atas 2 tahap yaitu tahap pertama dimulai dengan pelepasan pulp dari permukaan biji dan kedua reaksi hidrolitik didalam kotiledon biji. Perubahan jenis dan jumlah mikrobia selama berlangsungnya fermentasi biji kakao lebih dikenal dengan istilah suksesi mikrobia. Pada tahap awal fermentasi keberadaan mikrobia didominasi oleh yeast, selanjutnya diikuti oleh bakteri asam laktat dan akhir fermentasi oleh bakteri asam asetat (Aprotosoaie et al, 2016; Mulono, 2016). Aktivitas mikrobia tersebut menghasilkan etanol, asam laktat dan asam asetat selama fermentasi diikuti oleh kenaikan suhu lingkungan fermentasi. Alkohol dan asam asetat didifusi kedalam biji kakao dan diikuti oleh kenaikan suhu yang berdampak pada kematian biji (tidak dapat berkecambah).

Proses fermentasi kakao umumnya berlangsung secara alami dibantu oleh mikrobia dari udara berlangsung selama 6 hari serta dilakukan pembalikan pertama dihari ke 2 dan selanjutnya dilakukan pada setiap 24 jam (Afoakwa et al, 2014). S. cerevisiae memiliki beberapa kelebihan seperti pertumbuhannya sangat baik, toleran terhadap etanol, serta aktivitas pektinolitik dan tahan terhadap $\mathrm{pH}$ rendah. Lactobacillus sp yang dijumpai pada media fermentasi biji kakao segar adalah L. lactis, dengan kelebihannya yaitu lebih kompetitif, lebih toleran terhadap asam dan etanol dan tahan dikondisi lingkungan dengan jumlah oksigen lebih banyak. Bakteri asam asetat didominasi A. aceti dengan kemampuan tumbuh dikosentrasi etanol sampai $6,0 \%$, suhu $45^{\circ} \mathrm{C}$ dan pada $\mathrm{pH}$ 3,5 serta etanol dioksidasi menjadi asam asetat dan dikonversi lanjut asam asetat menjadi $\mathrm{CO}_{2}$ dan air (Cortes et al, 2012).
Penelitian ini bertujuan untuk mengetahui suksesi mikrobia dan perubahan kosentrasi etanol, asam laktat dan asam asetat selama fermentasi

\section{METODOLOGI PENENITIAN}

\section{Bahan}

Bahan yang digunakan dalam peneitian ini adalah ; buah kakao jenis lindak (bulk cacao) diperoleh dari desa Bunder, Patuk, Gunung Kidul, Yogyakarta dengan karakteristik yang dimiliki yaitu panjang buah $\pm 15 \mathrm{~cm}$, diameter $\pm 8 \mathrm{~cm}$, kulit buah masak optimal berwarna orange, jumlah biji tiap pod \pm 35 keping biji.

Kemudian nokulum $S$. cerevisiae (FNCC 3056), L. lactis (FNC 0086) dan A. aceti (FNCC 0016) diperoleh dari laboraturium mikrobiologi Pusat Studi Pangan dan Gizi Universitas Gadjah Mada. Aseton 80\%, BSA (bovien serum albumin), buffer pospat, asam asetat, tricloroacetat acid, $\mathrm{HCl}$, larutan buffer $\mathrm{pH} 4$, pH 7 dan $\mathrm{pH} 9$, hexan, larutan Folin-Ciocalteu, $\mathrm{Na}_{2} \mathrm{CO}_{3}$.

\section{Pelaksanaan Penelitian}

Fermentasi terkendali dengan penambahan inokulum mikrobia dan pengaturan suhu inkubator dengan perlakuan control mengacu Mulono et al., 2016b. Biji kakao kering terhidrasi yang digunakan pada tahap ini adalah yang terpilih. Biji kakao rehidrasi sebanyak 100 gram difermentasi selama $5 \times 24$ jam dengan tiga variasi perlakuan: a) tanpa penambahan inokulum disebut kontrol, b) dengan penambahan inokulum $S$. cerevisiae (FNCC 3056), L. lactis (FNC 0086) dan A. aceti (FNCC 0016) secara serentak pada awal fermentasi dengan populasi masing-masing sebanyak $10^{8} \mathrm{cfu} / \mathrm{g}$, dan c) dengan penambahan inokulum mikrobia secara bertahap sebagai berikut : $S$. cerevisiae (FNCC 
3056) pada awal 24 jam pertama, $L$. lactis (FNC 0086) pada awal 24 jam kedua dan A. aceti (FNCC 0016) pada awal 24 jam ketiga, masing masing dengan populasi sebanyak $10^{8} \mathrm{cfu} / \mathrm{g}$.

Fermentasi dilakukan secara berurutan dengan suhu terkendali: $35 \pm$ $0,1^{\circ} \mathrm{C}$ pada awal 24 jam pertama, $45 \pm$ $0,1{ }^{\circ} \mathrm{C}$ pada awal 24 jam kedua, $55 \pm$ $0,1^{\circ} \mathrm{C}$ pada awal 24 jam ketiga dan $35 \pm$ $0,1^{\circ} \mathrm{C}$ pada awal 24 jam keempat hingga jam ke 120. Total waktu fermentasi adalah 120 jam.

Pengujian jumlah $S$. cerevisiae, $L$. lactis dan $A$. aceti menggunakan metode pour plate count (Kustyawati dan Setyani, 2008), kosentrasi etanol, asam laktat dan asam asetat (metode Kresnowati et al, 2013).

\section{Rancangan Percobaan}

Rancangan percobaan yang dilakukan menggunakan Rancangan Acak Lengkap (RAL). Data seluruhnya dianalisa statistik secara oneway anova pada tingkat signifikasi $95 \%$ jika berbeda nyata dilanjutkan dengan uji lanjut LSD (least Significant different) menggunakan program SPSS 17.

\section{HASIL DAN PEMBAHASAN}

\section{Populasi Mikrobia awal}

Hasil penelitian menunjukan selama pengeringan biji kakao terjadi penurunan komposisi pulp biji kakao kering dan populasi $S$. cerevisiae, $L$. lactis dan A. aceti, untuk dapat berlansungnya proses fermentasi pulp biji kakao kering harus memenuhi syarat sebagai subtrat. Penurunan populasi S. cerevisiae karena air dalam pulp biji kakao menguap sehingga pertumbuhan $S$. cerevisiae terganggu dan menyebabkan kematian sel. L. lactis mengalami penurunan diduga karena suhu pengeringan menurunkan kadar air bebas sehingga bakteri tidak dapat tumbuh optimal. Pertumbuhan bakteri membutuhkan air bebas yang lebih banyak dibandingkan yeast. Pada proses pengeringan Aw turun, artinya air bebas yang tersisa tidak mencukupi untuk kebutuhan pertumbuhannya, walaupun pulp menyediakan nutrisi yang diperlukan.

Proses pengeringan menguapkan air dalam pulp serta seluruh alkohol hasil perombakan gula oleh $S$. cerevisiae berakibat pada tidak berkembang populasi A. aceti. Populasi S. cerevisiae, L. lactis dan A. aceti sebesar berturutturut $3,5 \times 10^{5} \mathrm{cfu} / \mathrm{g}, 4,7 \times 10^{6} \mathrm{cfu} / \mathrm{g}$ dan $4,2 \times 10^{4} \mathrm{cfu} / \mathrm{g} \quad(\mathrm{cfu}=$ Colony Forming Unit). Populasi $S$. cerevisiae, L. lactis dan A. aceti yang terdapat pada pulp biji kakao segar dan pulp biji kakao kering tersaji pada Tabel 1.

Tabel 1. Populasi S. cerevisiae, L. lactis dan A. aceti pada pulp biji kakao segar dan pulp biji kakao kering

\begin{tabular}{lcc}
\hline \multicolumn{1}{r}{ Mikrobia } & $\begin{array}{c}\text { Pulp biji kakao segar } \\
\text { (cfu/g) }\end{array}$ & $\begin{array}{c}\text { Pulp biji kakao kering } \\
\text { (cfu/g) }\end{array}$ \\
\hline S. cerevisiae & $4,5 \times 10^{6}$ & $3,5 \times 10^{5}$ \\
L. lactis & $4,2 \times 10^{7}$ & $4,7 \times 10^{6}$ \\
A. aceti & $4,6 \times 10^{5}$ & $4,2 \times 10^{4}$ \\
\hline
\end{tabular}


Hasil penelitian tahap ini menunjukan bahwa pada biji kakao kering telah memiliki populasi $S$. cerevisiae, L. lactis dan A. aceti, meskipun populasi tersebut belum memadahi untuk berlangsungnya fermentasi biji kakao terutama pada awal fermentasi, sejalan dengan penelitian Kresnowati et al (2013), dan Mulono et al, (2017).

\section{Suksesi Mikrobia}

Hasil penelitian ini menunjukan bahwa pada perlakuan kontrol populasi $S$. cerevisiae, L. lactis dan A. aceti di awal fermentasi berturut- turut 5,55, 6,66 dan 4,65 log (cfu/g). Hasil analisis statistik evaluasi hasil fermentasi melalui perubahan kimia dan mikrobiologi dengan perlakuan kontrol, IA dan IB tersaji pada Tabel 2.

Pada perlakuan kontrol diawal fermentasi kosentrasi etanol, asam laktat dan asam asetat seluruhnya $0 \%$. Pada 24 jam fermentasi terjadi perubahan populasi $S$. cerevisiae, L. lactis dan A. aceti berturut - turut yaitu 7,24; 6,70 dan $6,71 \log (\mathrm{cfu} / \mathrm{g})$. Kosentrasi etanol, asam laktat dan asam asetat berturut -turut yaitu 4,83, 1,83 dan 1,53\%. Pada 48 jam fermentasi populasi $S$. cerevisiae, $L$. lactis dan A. aceti masing - masing yaitu $5,88,8,66$ dan 6,64 log (cfu/g). Kosentrasi etanol, asam laktat dan asam asetat berturut - turut yaitu 2,63, 3,44 dan 2,35\%. Pada 72 jam fermentasi populasi $S$. cerevisiae, L. lactis dan A. aceti berturut - turut yaitu 4,23, 8,43 dan $6,11 \log (\mathrm{cfu} / \mathrm{g})$. Kosentrasi etanol, asam laktat dan asam asetat berturut - turut yaitu 1,02, 4,03 dan 3,46\%. Hasil analisis statistik ANOVA satu arah menunjukan bahwa rata - rata populasi S. cerevisiae perlakuan kontrol, IA dan IB berturut - turut yaitu 4,93, 5,86 dan 5,66 log (cfu/g) dan tidak berbeda nyata $(p \leq 0,05)$. Hal ini dapat diduga bahwa pengendalian suhu lingkungan menjadi ideal untuk pertumbuhan $S$. cerevisiae.

Rata - rata populasi L. lactis menunjukan bahwa perlakuan kontrol, penambahan inokulum secara serentak dan secara bertahap berturut - turut yaitu $6,90, \quad 8,6$ dan $8,55 \log (\mathrm{cfu} / \mathrm{g})$ dan perlakuan kontrol menunjukan berbeda nyata terhadap perlakuan yang lain. Rata- rata populasi $A$. aceti menunjukan bahwa perlakuan kontrol, penambahan inokulum secara serentak dan secara bertahap yaitu 5,57, 7,78 dan 8,74 log (cfu/g).

Hasil uji statistik menunjukan bahwa perlakuan kontrol berbeda nyata $(p \leq 0,05) \quad$ terhadap perlakuan penambahan inokulum secara serentak dan secara bertahap. Perubahan populasi $S$. cerevisiae, L. lactis dan A. aceti yang hasilkan perlakuan kontrol sesuai dengan hasil penelitian Kresnowati et al, (2013) dan Afoakwa et al, (2014), yang telah mempelajari pertumbuhan yeast, bakteri asam laktat dan bakteri asam asetat selama fermentasi biji kakao segar. Hasil analisis Anova penelitian ini menunjukan bahwa rata-rata produksi etanol, asam laktat dan asam asetat selama fermentasi tidak berbeda nyata $(p \leq 0,05)$ sesuai dengan hasil penelitian Kustyawati dan Setyani, (2008) yang telah mempelajari ekologi mikrobia pada fermentasi biji kakao di Indonesia.

Jika ditinjau kosentrasi etanol, asam laktat dan asam asetat selama fermentasi pada perlakuan kontrol masih relatif rendah, dapat diduga rendahnya kosentrasi etanol, asam laktat dan asam asetat disebabkan oleh populasi dan aktivitas $S$. cerevisiae, $L$. lactis dan A. aceti rendah. Rendahnya populasi dan aktivitas $S$. cerevisiae dapat disebabkan karena kondisi suhu dan $\mathrm{pH}$ yang tidak ideal, sejalan dengan hasil penelitian Ganda et al, (2008) bahwa kondisi suhu dan $\mathrm{pH}$ optimum aktivitas 
enzim poligalaturonase (PG) akan terjadi depolimerisasi pulp biji kakao.

Selajutnya hubungan populasi $S$. cerevisiae, L. lactis dan A. aceti terhadap konsentrasi etanol, asam laktat dan asam asetat biji kakao pada kontrol selama fermentasi tersaji pada Gambar 1.

Tabel 2. Hasil analisis statistik populasi S. cerevisiae, L. lactis, A. aceti, etanol, asam laktat, asam asetat, total polifenol dan asam amino hidrofobik.

\begin{tabular}{lccc}
\hline \multicolumn{1}{c}{ Parameter } & \multicolumn{3}{c}{ Perlakuan } \\
\cline { 2 - 4 } & Kontrol & IA & IB \\
\hline S. cerevisiae $(\log \mathrm{cfu} / \mathrm{g})$ & $4,93 \pm 0,35 \mathrm{a}$ & $5,86 \pm 0,95 \mathrm{a}$ & $5,66 \pm 0,05 \mathrm{a}$ \\
L. lactis $(\log \mathrm{cfu} / \mathrm{g})$ & $6,90 \pm 0,37 \mathrm{a}$ & $8,6 \pm 0,46 \mathrm{~b}$ & $8,55 \pm 0,66 \mathrm{~b}$ \\
A. aceti $(\log \mathrm{cfu} / \mathrm{g})$ & $5,57 \pm 0,27 \mathrm{a}$ & $7,78 \pm 0,48 \mathrm{~b}$ & $4,67 \pm 0,81 \mathrm{~b}$ \\
Etanol $(\%)$ & $1,81 \pm 0,50 \mathrm{a}$ & $1,93 \pm 0,57 \mathrm{a}$ & $1,94 \pm 0,6 \mathrm{a}$ \\
Asam laktat $(\%)$ & $2,64 \pm 0,37 \mathrm{a}$ & $2,47 \pm 0,39 \mathrm{a}$ & $2,54 \pm 0,40 \mathrm{a}$ \\
Asam asetat $(\%)$ & $3,09 \pm 0,58 \mathrm{a}$ & $3,25 \pm 0,62 \mathrm{a}$ & $3,43 \pm 0,70 \mathrm{a}$ \\
\hline
\end{tabular}

Keterangan: Huruf berbeda dibelakang angka pada baris sama menunjukan beda nyata $\mathrm{p} \leq 0,05$

Hasil rata-rata 2 ulangan dengan 3 ulangan analisis

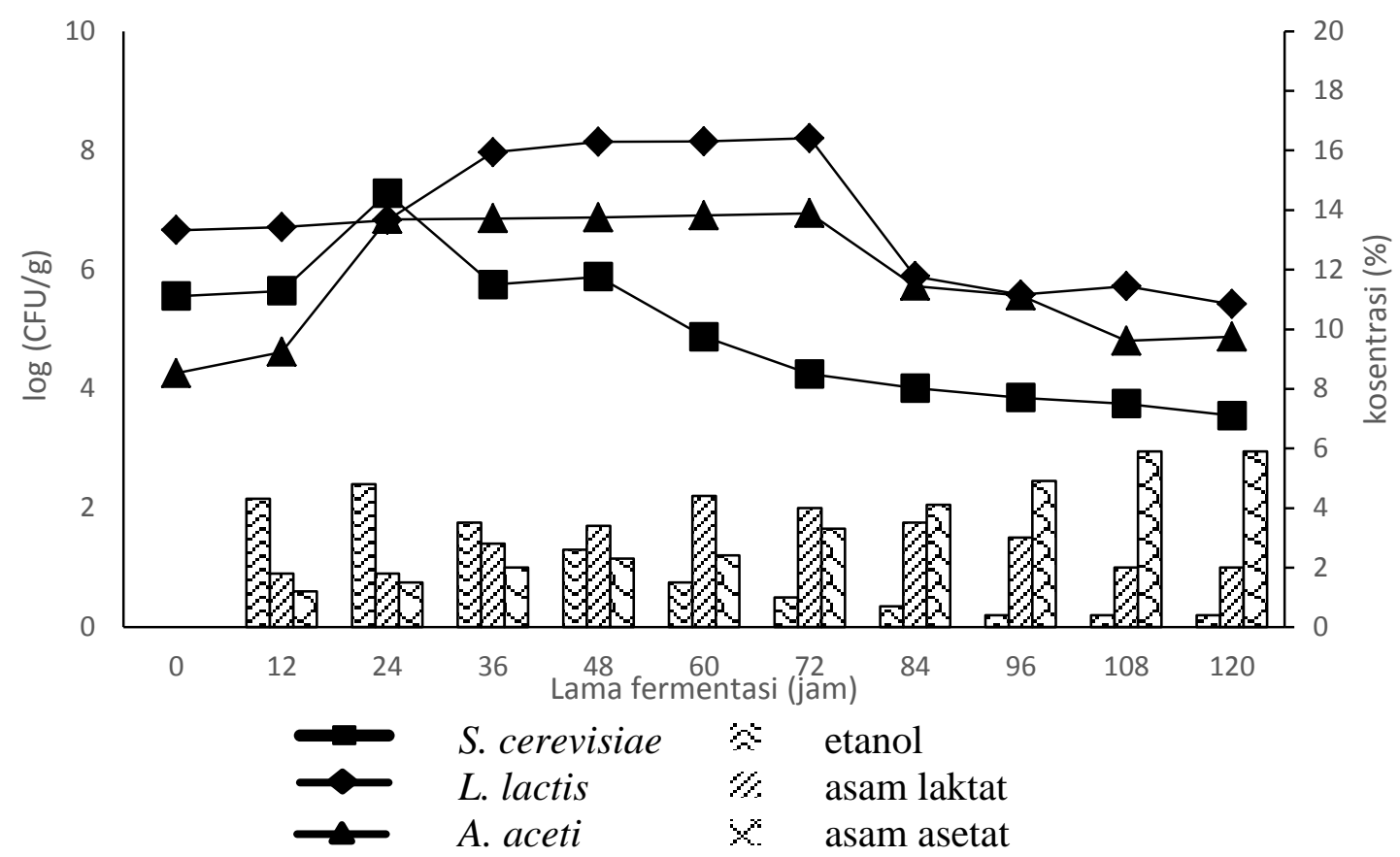

Gambar 1. Hubungan populasi S. cerevisiae, L. lactis dan A. aceti terhadap konsentrasi etanol, asam laktat dan asam asetat selama fermentasi biji kakao hasil perlakuan kontrol. Awal (0) - 24 jam fermentasi suhu inkubator $35^{\circ} \mathrm{C}, 24-48$ jam fermentasi suhu inkubator $45^{\circ} \mathrm{C}, 48-72$ jam fermentasi suhu inkubator $55^{\circ} \mathrm{C}$ dan $72-120$ jam fermentasi suhu inkubator $35^{\circ} \mathrm{C}$. 
Hasil penelitian ini pada perlakuan penambahan inokulum $S$. cerevisiae (FNCC 3056), L. lactis (FNCC 0086) dan A. aceti (FNCC 0016) secara serentak diawal fermentasi menunjukan bahwa populasi $S$. erevisiae, L. lactis, dan A. aceti diawal fermentasi berturut - turut yaitu 8,28, 8,58 dan 8,57 log (cfu/g).

Hubungan antara populasi $S$. cerevisiae, L. lactis dan A. aceti terhadap kosentrasi etanol, asam laktat dan asam asetat pada perlakuan penambahan inokulum secara serentak tersaji pada Gambar 2. Pada 24 jam fermentasi populasi S. cerevisiae, L. lactis, A. aceti masing - masing yaitu 12,41, 8,39 dan $8,38 \log (\mathrm{cfu} / \mathrm{g})$, terjadi kenaikan populasi $S$. cerevisiae dari awal fermentasi. Pada 48 jam fermentasi populasi S. cerevisiae, L. lactis, A. aceti berturut - turut 5,88, 11,82 dan 8,82 log $(\mathrm{cfu} / \mathrm{g})$, populasi L. lactis tertinggi terjadi di 48 jam fermentasi. pada 72 jam fermentasi populasi $S$. cerevisiae, $L$. lactis dan A. aceti berturut -turut yaitu 4,23, 9,11 dan 10,72 log (cfu/g), terjadi populasi $A$. aceti tertinggi disini. Selanjutnya populasi $S$. cerevisiae, $L$. lactis dan $A$. aceti menunjukan penurunan berturut - turut yaitu 2,5, 6,39 dan 5,45 log (cfu/g).

Jika ditinjau kosentrasi etanol, asam laktat dan asam asetat menunjukan berturut - turut diawal fermentasi yaitu 0\%. Pada 24 jam fermentasi dihasilkan kosentrasi etanol, asam laktat dan asam asetat berturut - turut yaitu 5,23, 1,433 dan 1,87\%. Pada 48 jam fermentasi dihasilkan kosentrasi etanol, asam laktat dan asam asetat berturut - turut yaitu $3,02,3,46$ dan 2,05\%. Pada jam ke 72 fermentasi menunjukan kosentrasi etanol, asam laktat dan asam asetat berturut - turut yaitu 1,35, 3,64 dan 3,54\%. Diakhir fermentasi menujukan penurunan kosentrasi etanol asam laktat dan asam asetat berturut - turut yaitu $0,33,1,82$ dan $6,32 \%$.

Kosentrasi etanol, asam laktat dan asam asetat yang dihasilkan lebih tinggi dari perlakuan kontrol dapat diduga bahwa penambahan inokulum meningkatkan populasi $S$. cerevisiae, $L$. lactis dan $A$. aceti sebanyak $10^{8}$ cfu/g.Setelah 24 jam fermentasi terjadi kenaikan suhu fermentasi dan $\mathrm{pH}$ lingkungan fermentasi berakibat pada kondisi optimum aktivitas enzim PG dan dihasilkan etanol lebih banyak sehingga kondisi tidak sesuai untuk $S$. cerevisiae dan perannya digantikan oleh $L$. lactis. Setelah 48 jam fermentasi subtrat gula sudah relatif sedikit, aerasi semakin baik dan kosentrasi etanol yang relatif tinggi, $\mathrm{pH}$ pulp semakin kecil menjadikan kondisi ideal untuk A. aceti.

Hasil analisis Anova satu arah menunjukan bahwa populasi L. lactis dan A. aceti pada perlakuan penambahan inokulum diawal berbeda nyata $(\mathrm{p} \leq 0,05)$ terhadap kontrol. Pertumbuhan populasi $S$. cerevisiae, $L$. lactis dan $A$. aceti yang dihasilkan sesuai dengan yang diperoleh Mulono et al., (2016a); yang telah mempelajari penambahan S. cerevisiae (FNCC 3056), L. lactis (FNCC 0086) dan A. aceti (FNCC 0016) pada proses fermentasi biji kakao segar varietas lindak. Hasil penelitian ini juga sesuai dengan hasil yang diperoleh Widianto et al,(2013) yang mempelajari perbaikan proses fermentasi dengan penambahan tetes tebu dan penambahan yeast, bakteri asam laktat dan bakteri asam asetat.

Hasil penelitian ini menunjukan bahwa perlakuan secara bertahap populasi S. cerevisiae, L. lactis dan A. aceti diawal fermentasi berturut - turut yaitu 8,66, 6,64 dan 4,67 log (cfu/g). Pada 24 jam fermentasi populasi $S$. cerevisiae, $L$. lactis dan $A$. aceti naik menjadi berturut - turut 12,55, 8,23 dan 
5,53 log (cfu/g). Pada 48 jam fermentasi populasi $S$. cerevisiae, L. lactis dan A. aceti terjadi perubahan berturut - turut yaitu 6,54, 12,53 dan 8,73 log (cfu/g). Pada 72 jam fermentasi populasi $S$. cerevisiae, L. lactis dan A. aceti berturut
- turut yaitu 3,87, 10,64 dan 12,13 log (cfu/g). Selanjutnya diakhir fermentasi populasi S. cerevisiae, L. lactis dan A. aceti turun menjadi berturut - turut 2,22, 6,23 dan 9,22 log cfu/g.

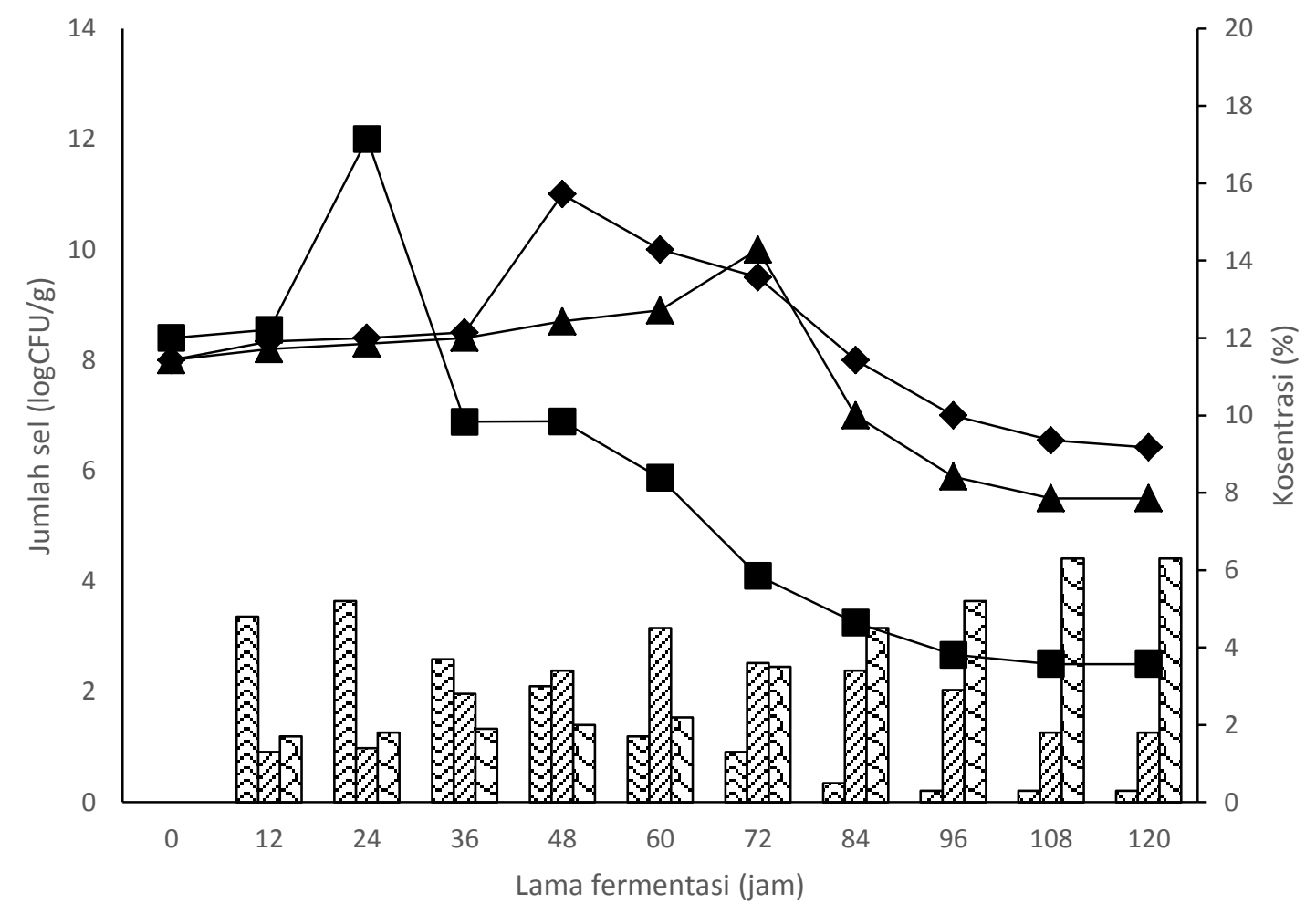

$\begin{array}{llll}\text { S. cerevisiae } & \stackrel{2}{*} & \text { etanol } \\ \text { L. lactis } & \mathscr{Z} & \text { asam laktat } \\ \text { A. aceti } & \times & \text { asam asetat }\end{array}$

Gambar 2. Hubungan populasi S. cerevisiae, L. lactis dan A. aceti terhadap konsentrasi etanol, asam laktat dan asam asetat selama fermentasi biji kakao hasil perlakuan penambahan inokulum secara serentak. Awal (0) 24 jam fermentasi suhu inkubator $35^{\circ} \mathrm{C}, 24-48$ jam fermentasi suhu inkubator $45^{\circ} \mathrm{C}, 48-72$ jam fermentasi suhu inkubator $55^{\circ} \mathrm{C}$ dan $72-$ 120 jam fermentasi suhu inkubator $35^{\circ} \mathrm{C}$

Perlakuan penambahan inokulum secara bertahap mempunyai kosentrasi etanol, asam laktat dan asam asetat diawal fermentasi seluruhnya $0 \%$. Pada 24 jam fermentasi ditunjukan kosentrasi etanol, asam laktan dan asam asetat naik berturut - turut yaitu 5,54, 1,55 dan
1,70\%. Pada 48 jam fermentasi menunjukan kosentrasi etanol, asam laktat dan asam asetat berturut - turut yaitu 2,84, 3,67 dan 2,37\%. Pada 72 jam fermentasi ditunjukan konsentrasi etanol, asam laktat dan asam asetat berturut turut yaitu 1,23, 3,83 dan 3,32\% sejalan 
dengan penelitian Campos et al, (2012), bahwa lama fermentasi akan menunjukan peningkatan senyawa asam organic yang menghasilkan senyawa aroma. Hubungan antara populasi $S$. cerevisiae, L. lactis dan A. aceti terhadap kosentrasi etanol, asam laktat dan asam asetat pada perlakuan penambahan inokulum secara bertahap tersaji pada Gambar 3.

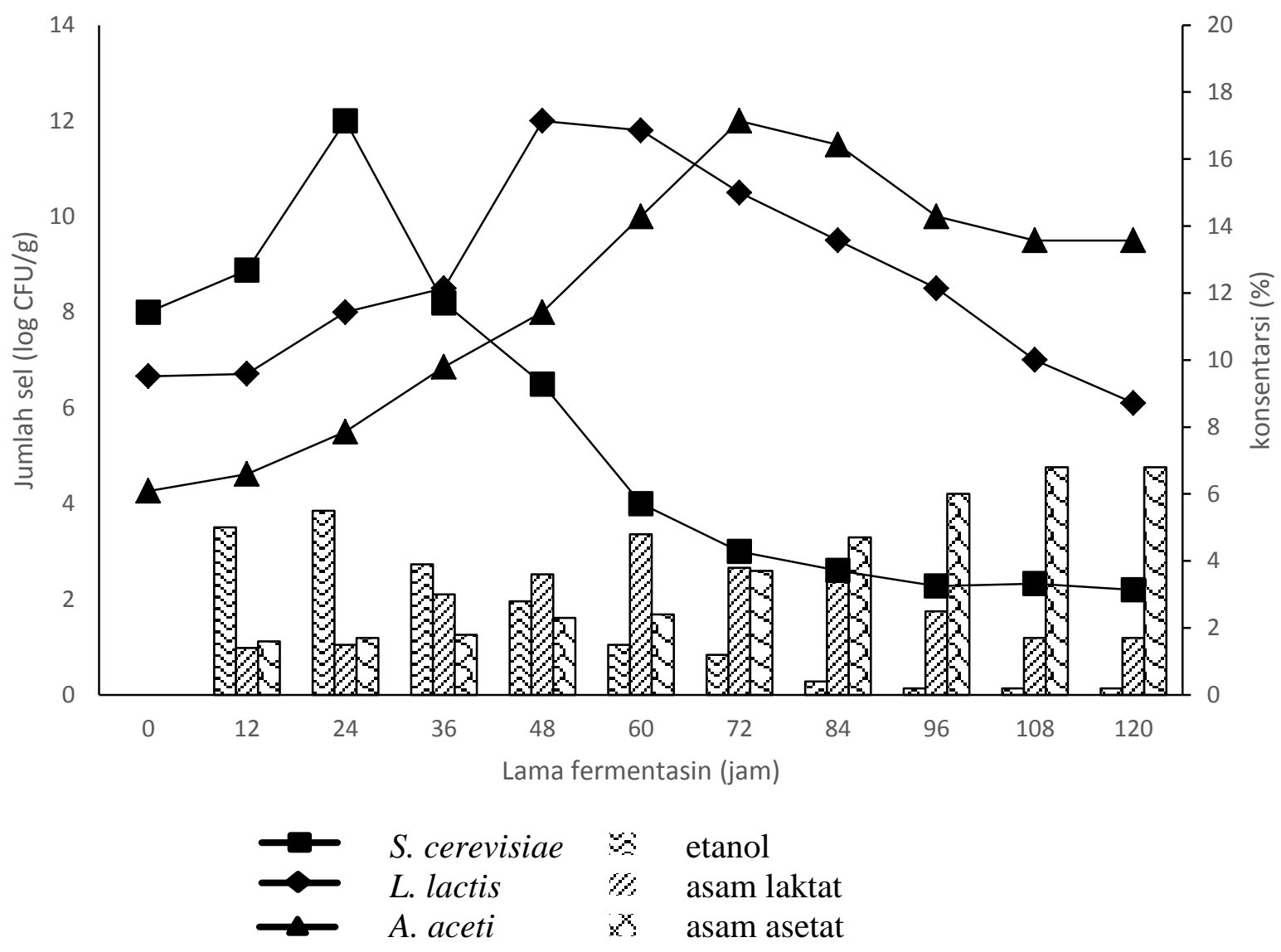

Gambar 3. Hubungan populasi S. cerevisiae, L. lactis dan A. aceti terhadap konsentrasi etanol, asam laktat dan asam asetat selama fermentasi biji kakao hasil perlakuan penambahan inokulum secara bertahap. Awal (0) -24 jam fermentasi suhu inkubator $35^{\circ} \mathrm{C}, 24-48$ jam fermentasi suhu inkubator $45^{\circ} \mathrm{C}, 48-72$ jam fermentasi suhu inkubator $55^{\circ} \mathrm{C}$ dan $72-$ 120 jam fermentasi suhu inkubator $35^{\circ} \mathrm{C}$

Kosentrasi etanol, asam laktat dan asam asetat tertinggi terjadi berturut turut di 24, 60, dan 108 jam fermentasi hal ini dapat diduga inokulum yang ditambahkan mengalami adaptasi dan kompetisi dengan mikrobia endogenus yang ada. Hasil analisis ANOVA satu arah menunjukan bahwa populasi $S$. cerevisiae, $L$. pada perlakuan inokulum secara bertahap tidak berbeda nyata terhadap perlakuan kontrol dan perlakuan penambahan inokulum secara serentak, sedangkan populasi L. lactis, populasi A. aceti berbeda nyata terhadap kontrol.

Perlakuan secara bertahap menujukan rata - rata populasi $S$. cerevisiae, L. lactis dan A. aceti berturut 
- turut yaitu 5,66, 8,55 dan 4,47 log (cfu/g). Jika ditinjau dari perlakuan variasi teknik fermentasi menunjukan kosentrasi etanol, asam laktat dan asam asetat naik, diduga suhu lingkungan yang dihasilkan penambahan inokulum yaitu $39-51^{\circ} \mathrm{C}$ merupakan suhu optimum untuk aktivitas enzim pektinolitik seperti enzim Poli Galaktoranase (PG) dan menaikan kemapuan depolimerisasi pulp biji kakao sejalan dengan hasil penelitian Ganda et al, (2008) yang melakukan optimasi kondisi depolimerisasi pulp biji kakao oleh enzim bahwa kondisi optimum untu aktivitas enzim PG pada suhu $42,5^{\circ} \mathrm{C}$ dan $\mathrm{pH} 4,6$. Jika ditinjau dari kosentrasi asam asetat yang dihasilkan maka dapat diartikan perlakuan secara bertahap adalah yang terbaik. Asam asetat merupakan asam organik yang terdifusi kedalam keping biji sehingga mengakibatkan aktifnya enzim polifenol oksidase yang mengoksidasi polifenol (Supriyanto et al, 2007).

\section{KESIMPULAN}

Rehidrasi pulp dapat meningkatkan kadar air pulp biji kakao kering sehingga dapat digunakan sebagai subtrat fermentasi. Mutu biji kakao hasil fermentasi dapat ditingkatkan melalui proses fermentasi terkendali. Perlakuan penambahan inokulum secara bertahap selama fermentasi dapat menaikan suhu fermentasi $\left(51^{\circ} \mathrm{C}\right)$, indeks fermentasi $(1,03)$, kadar gula reduksi $(10,79 \%)$, persentase jumlah warna coklat keping biji $(97,01 \%)$, kosentrasi asam asetat $(6,83 \%)$, populasi $S$. Cerevisiae $\left(10^{12}\right.$ cfu/g), L. lactis $\left(10^{12} \mathrm{cfu} / \mathrm{g}\right)$ dan A. aceti $\left(10^{12} \mathrm{cfu} / \mathrm{g}\right)$, meskipun $\mathrm{pH}$ biji kakao $(4,22)$ masih rendah dibandingkan perlakuan kontrol dan penambahan inokulum secara serentak fermentasi.

\section{DAFTAR PUSTAKA}

Afoakwa, E.O., Kongor, J. E.,Takrama, J. dan Budu, A. S., 2014. Changes in nib acidification and biochemical composition during fermentation of pulp preconditioned cocoa (Theobroma cacao) beans. Internasional Food Research Journal 20(4): 18431853

Aprotosoaie A. C., Luca S.V., dan Miron A., 2016. Flavor Chemistry of Cocoa and Cocoa Products-An Overview. Comprehensive Reviews in Food Science and Food Safety. 15: 73-91

Cortes, T.R.; Olvera,V.R., Jimenes, G.R., dan Lepe .M. R., 2012. Isol at ion and characterization of acetic acid bacteria in cocoa fermentation. African Journal of Microbiology Research. 6:339-347 Campos,R. J., Escalona-Buendía, H. B., Ramos.E.H.B., Avila, C.S.M, Flores, O.I. J.E., dan Cervantes, L.E., 2012. Effect of fermentation time and drying temperature on volatile compounds in cocoa. Food Chemistry, 132(1):277-288.

Ganda Putra, G.P., Harjiono, Susanto,T., Kumalaningsih,S., dan Aulanni'am, 2008. Optimasi kondisi depolimerisasi pulp biji kakao oleh enzim poligalakturonase endojinus. Jurnal Teknik Industri. 9(1): 12434.

Kresnowati P, M. T. A, Suryani, L dan Affifah, M., 2013. Improvement of Cocoa Beans Fermentation by LAB Starter Addition, Journal of Medical and Bioengineering. 2: 274-278.

Kustyawati M.E., dan Setyani S., 2008. Pengaruh penambahan inokulum campuran terhadap perubahan kimia dan mikrobiologi selama 
fermentasi coklat.Jurnal Teknologi Industri dan Hasil Pertanian. 8: 73 $-84$

Mulono Apriyanto, 2016. Changes in Chemical Properties of Dreid Cocoa (Theobroma cacao) Beans during Fermentation,. Intl. J. Food. Ferment. 5(1): 11-16, June 2016

Mulono Apriyanto., Sutardi., Harmayani, E., dan Supriyanto ., 2016a. Perbaikan proses fermentasi biji kakao non fermentasi dengan penambahan biakan murni saccharomyces cerevisiae, lactobacillus lactis , dan acetobacter aceti. Agritech 36, 410-415. doi:: .10.22146.

Mulono Apriyanto., Sutardi., E Harmayani., Supriyanto, 2016b.
Study on Effect of Fermentation to The quality parameter cocoa beans in Indonesia, Asian J. Dairy \& Food Res., 35 (2) 2016 : 160163.

Supriyanto, Haryadi, Rahardjo. B., dan Warseno. D.W., 2007. Perubahan suhu, kadar air, warna, kadar polifenol, dan aktivitas oksidatif kakao selama penyangraian dengan enerji gelombang mikro. AGRITECH. 27(1):176-182

Widianto, D., Pramita, A. D., dan Wedhastri, S., 2013. Perbaikan proses fermentasi biji kakao kering dengan penambahan tetes tebu, khamir, dan bakteri asam, Jurnal Tekno sains. 3(1):1-80 